\section{ECONOMICS}

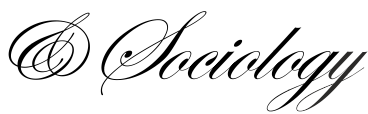

Fazaalloh, A. M. (2019). Is foreign direct investment helpful to reduce income inequality in Indonesia?. Economics and Sociology, 12(3), 25-36. doi:10.14254/2071789X.2019/12-3/2

\title{
IS FOREIGN DIRECT INVESTMENT HELPFUL TO REDUCE INCOME INEQUALITY IN INDONESIA?
}

\begin{abstract}
Al Muizzuddin Fazaalloh, Faculty of Economics and Business, Brawijaya University, Malang, Indonesia

E-mail:almuiz.wang@ub.ac.id ORCID 0000-0002-0526-9717
\end{abstract}

Received: January, 2019

1st Revision: March, 2019

Accepted: September, 2019

DOI: $10.14254 / 2071-$

789X.2019/12-3/2

\begin{abstract}
It is undeniable that foreign direct investments (FDI) are needed by many countries to push their economic growth. However, a trade-off between economic growth and income inequality, particularly in developing countries, frequently occurs. This paper examines the influence of FDI on income inequality in Indonesia. To estimate the relation of both variables, panel data regression model with panel-corrected standard errors (PCSE) technique was used to analyze provincial level data from 33 provinces over the period of 2012-2016. The study finds that FDI has a direct and insignificant effect on income inequality. Moreover, FDI has indirect and negative effects on income inequality, via economic growth. Interestingly, the indirect effects of FDI on income inequality through education and trade are statistically insignificant. In addition, non-linear relation between FDI and income inequality has not been proved.
\end{abstract}

Keywords: foreign direct investment, income inequality, panel data regression, Indonesia
JEL Classification: O15, F2, F63

\section{Introduction}

It is undeniable that every country needs foreign direct investment (FDI) to propel the economy. Moreover, it is clear that neoclassical and endogenous growth theory support FDI in influencing economic growth. However, a trade-off between economic growth and income inequality frequently happens. When the economic growth is high, the income distribution is usually low. This is caused by the incapability of FDI recipient countries in taking its advantage; the host country cannot absorb technological transfer brought by FDI and cannot provide employment from FDI activities.

This issue has attracted the attention of economists, urging them to conduct studies about the relationship between foreign direct investment and income inequality. In general, the results of their studies can be classified into three categories. First, FDI has a positive effect on income inequality, implying that the presence of FDI will exacerbate income inequality (Tsai, 1995; Sun \& Chai, 1998; Wu, 2005; Choi, 2006; Basu \& Guariglia, 2007; Clark et al, 2011; Wu \& Hsu, 2012; Jaumotte et al, 2013; Herzer et al, 2014; McLaren \& Yoo, 2017; Adams \& Klobodu, 2017; Bogliaccini \& Egan, 2017). Second, FDI has a negative effect on income inequality, which means that the inflow of FDI will reduce income inequality (Sylwester, 2005; Jensen \& Rosas, 2007; Chintrakarn et al, 2011; Ucal et al, 2016). Third, FDI has a negative and 
positive impact on income inequality (Figini \& Gorg, 2011; Herzer \& Nunnenkamp, 2013; Lessmann, 2013; Mihaylova, 2015; Chen, 2016; Kaulihowa \& Adjasi, 2017).

This paper investigates the impact of FDI inflow to host country on income inequality in Indonesia. At least there are three reasons why this study is important. First, there is no agreement among past studies about the impact of FDI on income inequality. This means that there are still opportunities to improve studies related to this topic. Second, Indonesia is one of the developing countries which is open for FDI. Recorded in the 2017 World Investment Report of UNCTAD (2017), Indonesia was in the fourth place below India, China, and the US in the list of favorable destination countries for foreign investors over the period of 2017-2019. Third, there are only a few studies in Indonesia addressing FDI's role in income inequality.

This study contributes to literature in three aspects. First, this study uses a new provincial-level data set, i.e. 33 provinces in Indonesia, over the period of 2012-2016. Second, this paper broadens previous studies using three interaction variables, namely growth, trade, and education, to point out how FDI determines income inequality indirectly. Third, this research also investigates the non-linear relationship between FDI and income inequality.

The rest of this paper is organized as follows. The first part discusses past studies that analyzed the relationship between FDI and income inequality. The second part explains the method of this study. The third part describes the results of the econometric models and discusses them. The last part presents conclusion and recommendation based on the findings of the study.

\section{Literature review}

This section explains the results of previous studies on how FDI affects income inequality. In general, based on their results, previous studies can be categorized into four.

The first category includes studies whose results indicate the positive impact of FDI on income inequality, meaning that FDI inflows to host country further aggravate the income inequality in the country. Using case studies in China, several researchers have proven this. Sun and Chai (1998) proved that the impact of FDI on economic growth is stronger in the eastern provinces. Wu (2005) concluded that, in China, the more competitive labor markets, the greater the income inequality becomes. This was due to an increase in wage gap between workers of state-owned enterprises and those of foreign companies. Lessmann (2013), who also used cases in China, found that FDI has a positive impact on regional income inequality after the 1980s reforms, but the effects disappeared after 1990.

Furthermore, some researchers also used more data to prove that FDI can widen distances in income distribution. Tsai (1995) found that FDI has a negative impact on the income distribution of less developed countries. Using the data from 119 countries during the 1993-2002 period, Choi (2006) found that increasing inequality is accompanied by increasing FDI. Basu and Guariglia (2007), using the data from 119 developing countries during the period of 1970-1999, found that FDI encourages economic growth yet aggravates income inequality. Wu and Hsu (2012), using the data from 54 countries in America, Asia and Oceania, Africa, and Europe over the period of 1980-2005, found that FDI jeopardizes the distribution of income in countries with low absorptive capacity. Herzer and Nunnenkamp (2013) conducted a research using the data from 8 European countries, i.e. Finland, Germany, Italy, Netherlands, Norway, Spain, Sweden, and United Kingdom, over the period of 1980-2000. They proved that FDI has a positive impact on income inequality in the short term in Europe. Jaumotte et al. (2013), using panel data from 51 countries over a 23-year period from 1981 to 2003, found that financial globalization identified with FDI increases income inequality. Herzer et al. (2014), through his research in Latin American countries, found that FDI has a significant and positive impact on income inequality. 
Recent studies also prove that FDI has a positive influence on income inequality. McLaren and Yoo (2017), using census data from Vietnam (1989-2009), proved that increasing FDI slightly decreases living standards. Adams and Klobodu (2017), using the data from 21 Sub-Saharan African countries over the period of 1984-2013, found that FDI has a positive and moderate impact on income inequality both in the short and long term. Bogliaccini and Egan (2017), using the ECM model with the data from 60 middle-income countries spread in Eastern Europe, Latin America, Southern Europe, Africa, and Southeast Asia over the period of 19892010, proved that the impact of FDI in service sector, which is the strongest in all sectors, is positive for income inequality.

The second category includes studies whose results indicate the negative impact of FDI on income inequality, implying that FDI inflows to host country decrease income inequality in the country. Jensen and Rosas (2007), using the data of 32 states in Mexico over the period of 1990-2000, found that an increase in FDI leads to a decrease in income inequality. Furthermore, they argued that FDI has a major impact on increasing the lower-middle class' income, but they were not sure about the cause. Chintrakarn et al. (2011), using state-level data in the United States found that, in the long run, FDI affects income inequality negatively, significantly, and robustly. Ucal et al. (2016) examined the impact of FDI on income inequality in Turkey in the short and long-term during the period of 1970-2008. They found that there is a cointegration between FDI and income inequality, where FDI has a negative impact on the Gini coefficient, which means that it can reduce income inequality in both short and long-term.

The third category includes studies that explained that the relationship between FDI and income inequality is non-linear. This relationship can be interpreted through two views: first, if the relationship between the two variables creates a U shape, the influence of FDI will initially be negative, and the effect will become positive after the turning point; second, if the relationship between the two variables creates a somewhat inverted U shape, FDI will have a positive effect from the initial condition to the turning point, and the influence becomes negative afterwards.

There are at least four studies that have proven this relationship. Figini and Gorg (2011), using the data of 103 countries over the period of 1980-2002, found that, in the case of developing countries, the relationship between FDI and income inequality is non-linear. Furthermore, the increase in income inequality coincides with the inflows of FDI stocks, but the effect fades after FDI increased significantly. As for developed countries, income inequality decreases with the inflows of FDI stocks, and their relationship is not robust in explaining the non-linear relationships. Mihaylova (2015), using data from ten Central and Eastern Europe (CEE) countries over the period of 1990-2012, found that FDI affects income inequality depending on the education and economic development of the host countries. At a lower level of human capital, on one hand, FDI increases income inequality. On the other hand, at a higher level of human capital, FDI reduces inequality. Chen (2016) found that FDI succeeds in reducing income inequality through job creation, knowledge transfer, and economic growth. However, FDI increases the imbalance of rural-urban income through international trade in China. Kaulihowa and Adjasi (2017), using data from sixteen African countries during 19802013, showed that FDI affects non-linear income inequality in a U shape. FDI improves income distribution in the tested countries, but further increases in FDI lead to increased inequality.

The final category includes studies showing that the effect of FDI on income inequality is insignificant, meaning that FDI is not related to income inequality. Sylwester (2005), using data in less developed countries during the period of 1970-1989, found that FDI has a positive impact on economic growth, but it was not proven to increase income inequality. Franco and Gerussi (2013), using data from seventeen transitional countries during 1990-2006, found that FDI has no significant impact on income distribution. 
Since previous studies have mixed results, the research on the impact of FDI on income inequality should be continued. There has not been enough number of studies concentrating in one country, except those that discuss China. Cases in developing countries still have to be explored. Therefore, this study concentrates its discussion in Indonesia. The consideration of choosing Indonesia is that this country has a very large population, which can be a factor of attraction for FDI, with a wide cultural heterogeneity and uneven regional economic development.

\section{Methodological approach}

\subsection{Empirical model}

To examine the impact of FDI on income inequality, panel data regression with panelcorrected standard errors (PCSE) technique was used since it enables the model of this study to be disassociated with autocorrelation and heteroscedasticity issues (Beck and Katz, 1995). The data of this study comes from 33 provinces in Indonesia over the period of 2012-2016, collected from Statistics Indonesia and BKPM, the Indonesian investment service agency.

The empirical model of this study was adapted from the model according to Kaulihowa and Adjasi (2017), Mihaylova (2015), and Figini \& Görg (2011) as follows.

$$
\begin{aligned}
& G_{I N I_{i t}}=\beta 0_{i t}+\beta 1 F D I_{i t}+\beta 2 F D I^{2}{ }_{i t}+\beta 3 G R O W T H_{i t}+\beta 4 E D U C A T I O N_{i t}+\beta 5 T R A D E_{i t}+
\end{aligned}
$$

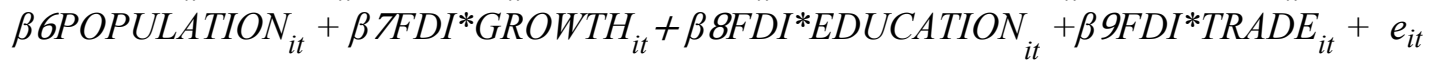

GINI denotes income inequality within province $\mathrm{i}$ in year $\mathrm{t}$ measured by Gini index (in percent). FDI denotes the foreign direct investment inflow to province $\mathrm{i}$ in year $\mathrm{t}$ as percentage of provincial GDP. FDI squared denotes FDI inflow added to the model to analyze the nonlinear relationship between income inequality and FDI. GROWTH denotes the economic growth of province $i$ in year $t$ measured by the growth of provincial GDP per capita (in percent). EDUCATION denotes the level of human capital of province $i$ in year $t$ measured by the log number of the population aged 15 years and over who are in labor force and graduated from upper secondary school. TRADE denotes international trade of province $i$ in year $t$ measured by the sum of export and import as the percentage of provincial GDP. POPULATION denotes the population of province $i$ in year $t$ measured by the log number of population. This study also includes three interactions variables namely the interaction between FDI and economic growth (FDI*GROWTH), the interaction between FDI and the level of human capital (FDI*EDUCATION), and the interaction between FDI and international trade (FDI*TRADE).

The squared FDI variable in this model was intended to see whether FDI has any effect on income inequality in a non-linear manner or not. Briefly, the relationship between FDI and income inequality will follow an inverted U shape. According to Kaulihowa \& Adjasi (2017), the effect of FDI on income inequality is expected to have a relationship in a U-shaped curve. That is, the effect of increasing FDI on inequality will decrease until it reaches a certain point, which in turn will increase income inequality. Meanwhile, according to Figini \& Görg (2011), the effect of FDI on income inequality will shape an inverted U curve. In this context, the increasing FDI will initially exacerbate income inequality to a certain point, and the effect of FDI will then be able to reduce income inequality.

The interaction variable between FDI and GROWTH, EDUCATION, and TRADE is intended to see the indirect effects of FDI on income inequality. Wooldridge (2016) explained that interaction variables can explain the partial effect of an explanatory variable on the dependent variable with dependence on other independent variables. In this model, the 
interaction between FDI and the three variables means that the effect of FDI on income inequality can be possible depending on economic growth, human capital quality, and trade. $\beta 7>0$ implies that an increase in FDI exacerbates income inequality for higher economic growth. $\beta 8>0$ implies that an increase in FDI worsen the income inequality for higher level human capital. Finally, $\beta 9>0$ implies that an increase in FDI increases income inequality for greater international trade.

Next, to see whether the explanatory variables of the model in this study are appropriate or whether one or more explanatory variables are missing in explaining the dependent variable, the regression specification test (RESET) was used. Gujarati \& Porter (2009) stated that the advantage of using RESET test is that we do not need to look for alternative models if the model we are testing has a miss-specified problem. However, this also becomes a weakness because, after knowing that a model turns out to be mis-specified, we cannot find a more appropriate alternative model. The null hypothesis in the RESET test is that the model used has no omitted variables. The alternative hypothesis explains that the model used has omitted variables. If the p-value of this test results is in a value greater than the significant level of $5 \%$, we fail to reject the null hypothesis, concluding that we do not need to add any explanatory variable to the model.

\subsection{Estimation strategy}

The impact of FDI on income inequality in this study was estimated in three steps. Firstly, the impact of FDI on income inequality was estimated by including control variables (growth, education, trade, and population). Secondly, the interaction between FDI and growth, the interaction between FDI and education, and the interaction between FDI and trade were added to the model. Finally, the non-linear relationship between FDI and income inequality was estimated. Interaction variables were used in the study to prove the indirect impact of FDI on income inequality, meaning that FDI can have an influence to income inequality through three channels.

\subsection{Data description}

Table 1 provides information about the descriptive statistic of all variables in the study. The Gini index ranges from 27.50 to 45.90 . Furthermore, FDI shows a huge disparity as the minimum value of FDI is 0.01 , and its maximum value is 46.77 . Similarly, the intervals between the maximum and minimum values of growth and trade are large. The minimum value of growth is -3.37 , and its maximum value of growth is 20.21 , while the maximum value of trade is 16.39 , and its maximum value is 328.52 . Those numbers clearly point out the uneven distribution of income in the provinces. The narrow interval can be seen on education and population, which ranges from 4.92 to 6.79 and from 5.79 to 7.68 .

Table 1. Descriptive statistic

\begin{tabular}{lrrrrr}
\hline Variable & Obs & Mean & Std. Dev. & Min & Max \\
\hline Gini & 167 & 37.146 & 4.018 & 27.500 & 45.900 \\
\hline FDI & 169 & 4.034 & 5.824 & 0.010 & 46.770 \\
\hline Growth & 168 & 3.986 & 2.508 & -3.370 & 20.210 \\
\hline Education & 167 & 5.735 & 0.452 & 4.920 & 6.790 \\
\hline Trade & 170 & 102.117 & 49.855 & 16.390 & 328.520 \\
\hline Population & 166 & 6.630 & 0.432 & 5.790 & 7.680 \\
\hline
\end{tabular}

Source: Author's calculation 
Table 2 shows the correlation matrix between FDI and income inequality. The correlation between FDI and Gini is very weak and positive (0.023). Furthermore, FDI is correlated positively with growth and trade, and it is corelated negatively with education and population.

Table 2. Correlation matrix

\begin{tabular}{lrrrrrr}
\hline & \multicolumn{1}{c}{ Gini } & \multicolumn{1}{c}{ FDI } & Growth & Education & Trade & Population \\
\hline Gini & 1.000 & & & & & \\
\hline FDI & 0.023 & 1.000 & & & & \\
\hline Growth & 0.213 & 0.020 & 1.000 & & & \\
\hline Education & 0.168 & -0.229 & -0.013 & 1.000 & & \\
\hline Trade & -0.089 & 0.045 & -0.174 & -0.081 & 1.000 & \\
\hline Population & 0.148 & -0.249 & 0.028 & 0.970 & -0.203 & 1.000 \\
\hline
\end{tabular}

Source: Author's calculation

Table 3 presents the Granger causality test results. It shows that there is a bi-directional causal relationship between FDI and education, Gini and education, growth and education, Gini and FDI, growth and FDI, population and FDI, Gini and growth, population and Gini, trade and Gini, trade and growth, and trade and population. In addition, there is a unidirectional causal relationship between population and education, trade and education, FDI and trade, and growth and population.

Table 3. Granger causality test results

\begin{tabular}{lcc}
\hline \multicolumn{1}{c}{ Pairs for causality } & F-statistic & Probability \\
\hline Gini $\rightarrow$ Education & 0.30796 & 0.7357 \\
\hline Education $\rightarrow$ Gini & 0.83619 & 0.4366 \\
\hline FDI $\rightarrow$ Education & 0.38980 & 0.6783 \\
\hline Growth $\rightarrow$ Education & 0.52654 & 0.5924 \\
\hline Education $\rightarrow$ Growth & 0.84806 & 0.4315 \\
\hline Education $\rightarrow$ FDI & 1.02537 & 0.3626 \\
\hline Trade $\rightarrow$ Education & 5.97719 & 0.0036 \\
\hline Education $\rightarrow$ Trade & 0.00504 & 0.9950 \\
\hline Population $\rightarrow$ Education & 13.5469 & $7 . E-06$ \\
\hline Education $\rightarrow$ Population & 0.14442 & 0.8657 \\
\hline Gini $\rightarrow$ FDI & 0.26786 & 0.7656 \\
\hline FDI $\rightarrow$ Gini & 0.54142 & 0.5837 \\
\hline Growth $\rightarrow$ FDI & 0.16313 & 0.8497 \\
\hline FDI $\rightarrow$ Growth & 0.97065 & 0.3826 \\
\hline Population $\rightarrow$ FDI & 0.72218 & 0.4884 \\
\hline FDI $\rightarrow$ Population & 0.66676 & 0.5158 \\
\hline Trade $\rightarrow$ FDI & 0.22074 & 0.8023 \\
\hline FDI $\rightarrow$ Trade & 6.30773 & 0.0027 \\
\hline Growth $\rightarrow$ Gini & 0.53241 & 0.5889 \\
\hline Gini $\rightarrow$ Growth & 0.26188 & 0.7702 \\
\hline Population $\rightarrow$ Gini & 0.77388 & 0.4641 \\
\hline Gini $\rightarrow$ Population & 0.69189 & 0.5032 \\
\hline Trade $\rightarrow$ Gini & 0.57759 & 0.5632 \\
\hline Gini $\rightarrow$ Trade & 0.64017 & 0.5295 \\
\hline Population $\rightarrow$ Growth & 0.46980 & 0.6266 \\
\hline Growth $\rightarrow$ Population & 2.82546 & 0.0643 \\
\hline Trade $\rightarrow$ Growth & 1.14798 & 0.3216 \\
\hline Growth $\rightarrow$ Trade & 0.90629 & 0.4075 \\
\hline & &
\end{tabular}




\begin{tabular}{lll}
\hline Trade $\rightarrow$ Population & 0.40106 & 0.6707 \\
\hline Population $\rightarrow$ Trade & 0.14174 & 0.8680 \\
\hline
\end{tabular}

Source: Author's calculation

\section{Conducting research and results}

Table 4 presents the regression results of the four models. The result of the baseline regression is reported in model 1. In the same vein as Sylwester (2005) and Franco and Gerussi (2013), the result proves that FDI does not have any significant impact on income inequality, and this result is robust with model 3 and 4, except in model 2, which suggests that the impact of FDI on income inequality is statistically significant and positive. This suggests that there is no direct relationship between FDI and income inequality. However, the magnitude of FDI coefficient is positive, meaning that the increasing FDI may exacerbate income inequality.

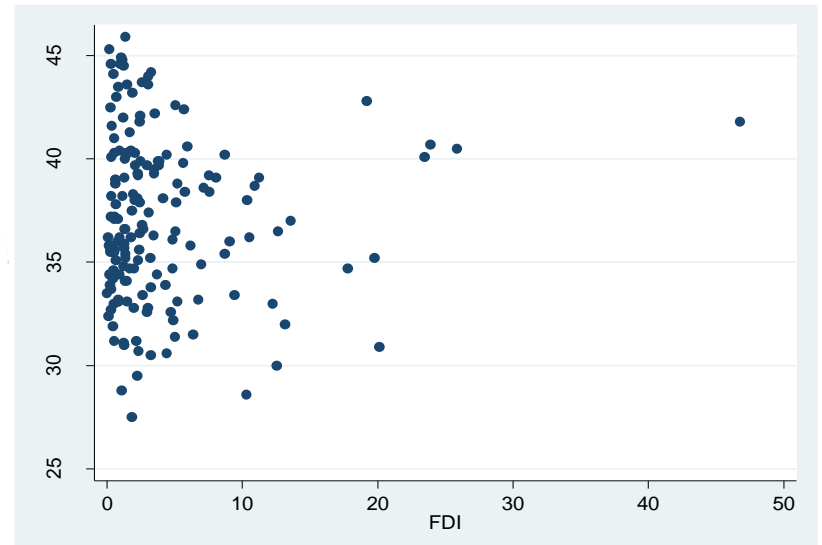

Figure 1. The scatter plot between FDI and income inequality from data of 33 provinces in Indonesia (2012-2016)

Source: Author's calculation

As shown in the scatter plot in figure 1, there is a pattern showing that the contribution of FDI to provincial GDP tends to be low, and then the contribution of income inequality in the provinces is high. This scatter plot reinforces the result that FDI may have a positive influence on income inequality although its impact is weak.

Economic growth has a positive and statistically significant effect on income inequality. The result is robust with the remaining models, implying that when economic growth is increasing, income inequality becomes higher. Furthermore, the coefficient of economic growth in model 1 can be interpreted as that one percent increase in economic growth is associated with an increase of 0.35 percent in income inequality. Rubin and Segal (2015) argued that the positive correlation between economic growth and income inequality can be caused by the enormous portion received by the highest income shares in a country and that this condition is profound to economic growth rather than worker's salary. In the case of Indonesia, the issue seems to be true as the rich provinces are centered in Java.

Education is positively and statistically significant for income inequality. The result is robust in all models, which means that the higher in the number of labors graduated from secondary school, the wider the income gap. It can be interpreted that, according to education coefficient in model 1, one percent increase in number of labors is associated with an increase of 6.88 percent in income inequality. This finding is in line with Coady and Dizioli (2017), who found that disparity in schooling is correlated positively with income inequality. Moreover, the calculation of this study confirms that about 56 percent of educated labors are concentrated in 
Java. This indicates that there is a huge disparity between the education of labors in Java and that of outside Java.

Trade has a negative and statistically significant impact on income inequality. The result is robust in all models except in model 4 , yet the trade coefficient in model 4 remains negative. The coefficient of trade in model 1 can be interpreted as that one percent increase in trade is associated with a decrease of 0.01 percent in income inequality. This means that increased export and import activity reduces income inequality. At least there are two reasons that can be used as the argument for the result: first, a region with disclosure to export tends to be successful in reducing income inequality (Castilho et al, 2012); second, based on the research in Indonesia, Kis-Katos and Sparrow (2015) found that income inequality can be diminished by the openness of a region to liberalization of input tariff.

The effect of population is statistically significant and negative on income inequality. The result is also robust in all models. This suggests that the increase of population decreases income inequality. The coefficient of population in model 1 might be interpreted as that one percent increase in population is expected to reduce income inequality for 5.75 percent. Dong et al. (2018) argued that the increasing income inequality in China is associated with population aging. However, as in Indonesia, the impact of population is negative, thus Indonesia may benefit from its demographic structure since the number of young people in the population is higher than that of old people.

Table 4. Empirical results of the linear impact of FDI on income inequality

\begin{tabular}{|c|c|c|c|c|}
\hline Independent variables & Model 1 & Model 2 & Model 3 & Model 4 \\
\hline FDI & $\begin{array}{c}0.0311 \\
(0.0292)\end{array}$ & $\begin{array}{c}0.338 * * * \\
(0.0672)\end{array}$ & $\begin{array}{c}0.642 \\
(0.604)\end{array}$ & $\begin{array}{c}0.428 \\
(0.814)\end{array}$ \\
\hline Growth & $\begin{array}{c}0.351 * * * \\
(0.107)\end{array}$ & $\begin{array}{c}0.843 * * * \\
(0.167)\end{array}$ & $\begin{array}{c}0.839 * * * \\
(0.170)\end{array}$ & $\begin{array}{c}0.835^{* * *} * \\
(0.172)\end{array}$ \\
\hline Education & $\begin{array}{c}6.878 * * * \\
(2.615)\end{array}$ & $\begin{array}{c}7.393 * * * \\
(2.312)\end{array}$ & $\begin{array}{c}7.471 * * * \\
(2.208)\end{array}$ & $\begin{array}{c}7.489 * * * \\
(2.167)\end{array}$ \\
\hline Trade & $\begin{array}{l}-0.00921^{*} \\
(0.00476)\end{array}$ & $\begin{array}{l}-0.00868^{*} \\
(0.00457)\end{array}$ & $\begin{array}{l}-0.00855^{*} \\
(0.00453)\end{array}$ & $\begin{array}{c}-0.0115 \\
(0.00824)\end{array}$ \\
\hline Population & $\begin{array}{c}-5.753 * * \\
(2.682)\end{array}$ & $\begin{array}{c}-6.099 * * \\
(2.390)\end{array}$ & $\begin{array}{c}-5.980 * * \\
(2.493) \\
\end{array}$ & $\begin{array}{c}-6.082 * * \\
(2.438)\end{array}$ \\
\hline FDI*Growth & & $\begin{array}{c}-0.0767 * * * \\
(0.0159)\end{array}$ & $\begin{array}{c}-0.0752 * * * \\
(0.0171)\end{array}$ & $\begin{array}{c}-0.0742^{* * * *} \\
(0.0170)\end{array}$ \\
\hline FDI*Education & & & $\begin{array}{l}-0.0587 \\
(0.122) \\
\end{array}$ & $\begin{array}{l}-0.0346 \\
(0.135) \\
\end{array}$ \\
\hline FDI*Trade & & & & $\begin{array}{l}0.000751 \\
(0.00203)\end{array}$ \\
\hline Constant & $\begin{array}{c}35.27 * * * \\
(4.115)\end{array}$ & $\begin{array}{l}32.60 * * * \\
(3.793)\end{array}$ & $\begin{array}{c}31.45^{* * *} \\
(5.374)\end{array}$ & $\begin{array}{l}32.31 * * * \\
(5.461)\end{array}$ \\
\hline Observations & 165 & 165 & 165 & 165 \\
\hline R-squared & 0.096 & 0.159 & 0.159 & 0.160 \\
\hline Number of regions & 33 & 33 & 33 & 33 \\
\hline Wald chi ${ }^{2}$ & 35.75 & 47.18 & 52.64 & 52.87 \\
\hline $\begin{array}{l}\text { Diagnostic test: } \\
\text { RESET test (F-stat) }\end{array}$ & - & $6.32^{* * *}$ & $5.55^{* * *}$ & $4.95 * * *$ \\
\hline
\end{tabular}

Source: Author's calculation

Notes: Standard errors in parentheses. $* * * \mathrm{p}<0.01, * * \mathrm{p}<0.05, * \mathrm{p}<0.1$ 
In model 2, the interaction variable between FDI and economic growth was added. This interaction variable is associated negatively and statistically significant to income inequality. The result is also robust for model 3 and model 4, meaning that the impact of FDI on income inequality is indirect via economic growth. This indicates that the increase of FDI inflows enhances economic growth, and hence income inequality will decrease. The role of FDI in increasing economic growth, as endogenous theory has explained, is that multinational company (MNC) will expand the physical capital and knowledge transfer in host country (Mehic et al., 2013). Moreover, the knowledge transfer by MNC will benefit domestic firms in catching up the advancement of technology brought by MNC. Therefore, the wages of unskilled labors in domestic firms will increase along with the improvement of their skill. Finally, the higher the wages, the lower the income gap.

In model 3, the second interaction variable, i.e. the interaction between FDI and education, was added. The variable is statistically insignificant, but the coefficient is negative. Thus, the effect of FDI on education will negatively induce income inequality. The fact that education is one of the important factors for reducing income inequality is based on the study by Borensztein et al. (1998), which revealed that host country can benefit from FDI inflows if the human capital in the country is in the minimum threshold. Therefore, if the interaction between FDI and education cannot influence income equality positively, it might be caused by the low level of education in the host country.

Similar result is also presented in model 4, which the interaction variable between FDI and trade is statistically insignificant, and the coefficient is positive. It is expected that the effect of this variable increases income inequality. The result indicates that trade may not be a channel for FDI to influence income inequality.

Table 5 presents the non-linear model between FDI and income inequality. In contrast to Kaulihowa and Adjasi (2017), the result of model 5 points out that FDI does not correlate nonlinearly with income inequality. This is because the effect of FDI squared on income inequality is statistically insignificant; only FDI has a significant effect on income inequality. Moreover, the result cannot confirm the modernization theory as suggested by Kuznet, in which income inequality is associated with the stage of economic development (Kaulihowa and Adjasi, 2017). The theory explains that an increase in FDI in the initial stages of economic development in a country exacerbates income inequality. However, after the development stage in the economy has reached its maximum point, income inequality will be reduced.

Table 5. Empirical results of the non-linear impact of FDI on income inequality

\begin{tabular}{lc}
\hline Independent variables & Model 5 \\
\hline FDI & $-0.157^{*}$ \\
& $(0.0939)$ \\
\hline FDI $^{2}$ & 0.00650 \\
& $(0.00406)$ \\
\hline Growth & $0.360^{* * *}$ \\
& $(0.115)$ \\
\hline Education & $7.014 * * *$ \\
& $(2.430)$ \\
\hline Prade & $-0.00910^{* *}$ \\
& $(0.00419)$ \\
\hline Copulation & $-5.776^{* *}$ \\
\end{tabular}




\begin{tabular}{lc}
\hline Observations & 165 \\
\hline R-squared & 0.118 \\
\hline Number of regions & 33 \\
\hline Wald chi $^{2}$ & 43.39 \\
Diagnostic test: & $4.15^{* * *}$ \\
RESET test (F-stat) & \\
\hline
\end{tabular}

Source: Author's calculation

Notes: Standard errors in parentheses

$* * * \mathrm{p}<0.01, * * \mathrm{p}<0.05, * \mathrm{p}<0.1$

\section{Conclusion}

This paper addresses the effect of FDI on income inequality in Indonesia over the period of 2012-2016 using the data from 33 provinces. To deal with classical issues in the regression model (autocorrelation and heteroscedasticity), panel data regression using panel-corrected standard errors (PCSE) was applied. The impact of FDI on income inequality is declared statistically insignificant in the linear model. However, the coefficient of FDI is positive, so it can be expected that increased FDI causes wider income inequality. In addition, this study offers a new view about the impact of FDI on income inequality: the impact is indirect. The indirect effect of FDI on income inequality can be revealed by the interaction between FDI and economic growth, FDI and education, and FDI and trade. The result conveys that FDI only has indirect effects on income inequality through economic growth, whose effect is negative. Meanwhile, its indirect effect through education and trade was not proven. Furthermore, in a non-linear relation, FDI is declared insignificant for income inequality.

Based on the Indonesia case, policy makers should notice the linkages between FDI and economic growth, as the interaction between FDI and economic growth generates reduction in income inequality. Further, in order to benefit more from FDI inflow, host countries should improve the quality of their human capital by better educating of their labors. This means that improving the quality of human capital will increase the supply of skilled labor, and in the end income can be equally distributed (Kaulihowa \& Adjasi, 2017).

For future studies, the appropriate econometric model is a crucial issue in examining the relationship between FDI and income inequality. The issue such as endogeneity between FDI and income inequality should be considered in analyzing the relationship between the two variables. In addition, the use of control variables determines the accuracy of the model. Future researches can add more control variables such as government size, corruption, and disaster to explain the impact of FDI on income equality better.

\section{Acknowledgement}

The deepest gratitude is addressed to the Economics Department, Faculty of Economics and Business, Brawijaya University for their financial support in this study and to anonymous comments that improve this paper.

\section{References}

Adams, S., \& Klobodu, E. K. M. (2017). Capital flows and the distribution of income in subSaharan Africa. Economic Analysis and Policy, 55, 169-178. https://doi.org/10.1016/j.eap.2017.05.006 
Basu, P., \& Guariglia, A. (2007). Foreign direct investment, inequality, and growth. Journal of Macroeconomics, 29(4), 824-839. https://doi.org/10.1016/j.jmacro.2006.02.004

Bogliaccini, J. A., \& Egan, P. J. W. (2017). Foreign direct investment and inequality in developing countries: Does sector matter? Economics and Politics, 29(3), 209-236. https://doi.org/10.1111/ecpo.12098

Borensztein, E., De Gregorio, J., \& Lee, J. W. (1998). How does foreign direct investment affect economic growth? 1. Journal of international Economics, 45(1), 115-135. https://doi.org/10.1016/S0022-1996(97)00033-0

Castilho, M., Menéndez, M., \& Sztulman, A. (2012). Trade liberalization, inequality, and poverty in Brazilian states. World Development, 40(4), 821-835.

Chen, C. (2016). The impact of foreign direct investment on urban-rural income inequality. China Agricultural Economic Review, 8(3), 480-497. https://doi.org/10.1108/CAER09-2015-0124

Chintrakarn, P., Herzer, D., \& Nunnenkamp, P. (2012). FDI and income inequality: Evidence from a panel of U.S. states. Economic Inquiry, 50(3), 788-801. https://doi.org/10.1111/j.1465-7295.2011.00384.x

Choi, C. (2006). Does foreign direct investment affect domestic income inequality? Applied Economics Letters, 13(12), 811-814. https://doi.org/10.1080/13504850500400637

Clark, D. P., Highfill, J., de Oliveira Campino, J., \& Rehman, S. S. (2011). FDI, technology spillovers, growth, and income inequality: A selective survey. Global Economy Journal, 11(2). https://doi.org/10.2202/1524-5861.1773

Coady, D., \& Dizioli, A. (2017). Income inequality and education revisited: persistence, endogeneity and heterogeneity. Applied Economics, 50(25), 2747-2761. https://doi.org/10.1080/00036846.2017.1406659

Dong, Z., Tang, C., \& Wei, X. (2018). Does population aging intensify income inequality? Evidence from China. Journal of the Asia Pacific Economy, 23(1), 66-77. https://doi.org/10.1080/13547860.2017.1354270

Figini, P., \& Görg, H. (2011). Does foreign direct investment affect wage inequality? An empirical investigation. World Economy, 34(9), 1455-1475. https://doi.org/10.1111/j.1467-9701.2011.01397.x

Franco, C., \& Gerussi, E. (2013). Trade, foreign direct investments (FDI) and income inequality: Empirical evidence from transition countries. Journal of International Trade and Economic Development, 22(8), 1131-1160. https://doi.org/10.1080/09638199.2011.647048

Gujarati, D. N. Porter. D. C (2009). Basic Econometrics, 5e. McGraw-Hill.

Herzer, D., Hühne, P., \& Nunnenkamp, P. (2014). FDI and Income Inequality-Evidence from Latin American Economies. Review of Development Economics, 18(4), 778-793. https://doi.org/10.1111/rode.12118

Herzer, D., \& Nunnenkamp, P. (2013). Inward and outward FDI and income inequality: Evidence from Europe. Review of World Economics, 149(2), 395-422. https://doi.org/10.1007/s10290-013-0148-3

Jaumotte, F., Lall, S., \& Papageorgiou, C. (2013). Rising income inequality: Technology, or trade and financial globalization? IMF Economic Review, 61(2), 271-309. https://doi.org/10.1057/imfer.2013.7

Kaulihowa, T., \& Adjasi, C. (2017). FDI and income inequality in Africa. Oxford Development Studies, 818(October), 1-16. https://doi.org/10.1080/13600818.2017.1381233

Kis-Katos, K., \& Sparrow, R. (2015). Poverty, labor markets and trade liberalization in Indonesia. Journal of Development Economics, 117, 94-106.

Lessmann, C. (2013). Foreign direct investment and regional inequality: A panel data analysis. China Economic Review, 24(1), 129-149. https://doi.org/10.1016/j.chieco.2012.12.001 
McLaren, J., \& Yoo, M. (2017). FDI and inequality in Vietnam: An approach with census data. Journal of Asian Economics, 48, 134-147. https://doi.org/10.1016/j.asieco.2016.11.002

Mehic, E., Silajdzic, S., \& Babic-Hodovic, V. (2013). The impact of FDI on economic growth: Some evidence from southeast Europe. Emerging Markets Finance and Trade, 49(sup1), 5-20. http://dx.doi.org/10.2753/REE1540-496X4901S101

Mihaylova, S. (2015). Foreign direct investment and income inequality in Central and Eastern Europe. Theoretical and Applied Economics, XXII (2603), 23-42. https://doi.org/10.1017/CBO9780511488597.006

Rubin, A., \& Segal, D. (2015). The effects of economic growth on income inequality in the US. Journal of Macroeconomics, 45, 258-273.

Sun, H., \& Chai, J. (1998). Direct foreign investment and inter-regional economic disparity in China. International Journal of Social Economics, 25(2/3/4), 424-447. https://doi.org/10.1108/03068299810193687

Sylwester, K. (2005). Foreign direct investment, growth and income inequality in less developed countries. International Review of Applied Economics, 19(3), 289-300. https://doi.org/10.1080/02692170500119748

Tsai, P.-L. (1995). Foreign Direct Investment and Income Inequality: Further Evidence. World Development, 23(3), 469-483. https://doi.org/10.1016/0305-750X(95)00136-Z

Ucal, M., Haug, A. A., \& Bilgin, M. H. (2016). Income inequality and FDI: evidence with Turkish data. Applied Economics, 48(11), 1030-1045. https://doi.org/10.1080/00036846.2015.1093081

UNCTAD (2017). World Investment Report 2017. Geneva: United Nations.

Wooldridge, J. M. (2016). Introductory Econometrics: A Modern Approach, 6e. Cengage Learning.

Wu, J. Y., \& Hsu, C. C. (2012). Foreign direct investment and income inequality: Does the relationship vary with absorptive capacity? Economic Modelling, 29(6), 2183-2189. https://doi.org/10.1016/j.econmod.2012.06.013

$\mathrm{Wu}, \mathrm{X}$. (2005). Will foreign capital inflow alleviate income inequality? Journal of the Asia Pacific Economy, 10(4), 528-550. https://doi.org/10.1080/13547860500335211

Yu, K., Xin, X., Guo, P., \& Liu, X. (2011). Foreign direct investment and China's regional income inequality. Economic Modelling, 28(3), 1348-1353. https://doi.org/10.1016/j.econmod.2011.02.026 